Two distinctive new species of Commicarpus (Nyctaginaceae) from gypsum outcrops in eastern Ethiopia.

Friis, Ib; Gilbert, Michael G.; Weber, Odile; Demissew, Sebsebe

Published in:

Kew Bulletin

DOI:

10.1007/s12225-016-9648-3

Publication date:

2016

Document version

Early version, also known as pre-print

Document license:

Unspecified

Citation for published version (APA):

Friis, I., Gilbert, M. G., Weber, O., \& Demissew, S. (2016). Two distinctive new species of Commicarpus (Nyctaginaceae) from gypsum outcrops in eastern Ethiopia. Kew Bulletin, 71, [34].

https://doi.org/10.1007/s12225-016-9648-3 


\title{
Two distinctive new species of Commicarpus (Nyctaginaceae) from gypsum outcrops in eastern Ethiopia
}

\author{
Ib Friis ${ }^{1}$, Michael G. Gilbert ${ }^{2}$, Odile Weber $^{2}$ \& Sebsebe Demissew $^{3}$
}

Summary: During field trips in 2013 and 2014 two distinctive plants belonging to the genus Commicarpus were collected in the Lele Hills, Bale Zone, eastern Ethiopia, on outcrops of sedimentary rock belonging to the Gorrahei Formation with high contents of gypsum. The plants are here described as two new species: Commicarpus macrothamnus Friis \& O. Weber, sp. nov., is unique among all hitherto described species of Commicarpus, being a robust free standing shrub, almost a small tree up to $3 \frac{1}{2} \mathrm{~m}$ high, with woody stems up to ca. $12 \mathrm{~cm}$ in diam. Commicarpus leleensis Friis \& Sebsebe, sp. nov., is also unusual in Commicarpus, being a small self-supporting shrub to $0.8(-1) \mathrm{m}$ high. Both new species occur in small populations with restricted distribution; models based on the available information show that also the potential distribution is restricted. Commicarpus macrothamnus is here evaluated as Vulnerable (VU), while C. leleensis, only known

${ }^{1}$ Biosystematics, Natural History Museum of Denmark, University of Copenhagen, Sølvgade 83, DK-1305 Copenhagen K, Denmark. ibf@snm.ku.dk

${ }^{2}$ Herbarium, Library and Archives, Royal Botanic Gardens, Kew, Richmond, Surrey, TW9 3AB, England, UK.

${ }^{3}$ The National Herbarium, Department of Plant Biology and Biodiversity, Addis Ababa University, P.O. Box 3434, Addis Ababa, Ethiopia. 
from the type, should remain Data Deficient (DD). Outcrops of gypsum with restricted-range species are well known from eastern Ethiopia and Somalia, but the locality with the two new species of Commicarpus is the most north-western and one of the highest sites recorded so far for gypsum endemics.

Key Words. conservation, ecology, Gorrahei Formation, inflorescence, narrow endemics, shrubby habit, taxonomy.

\section{Introduction}

During a field trip to the Bale zone, Oromia Regional State, Ethiopia, in Dec. 2013 Odile Weber and Ib Friis studied unusual Acacia-Commiphora woodland on hills ca. $105-115 \mathrm{~km}$ east of the town of Ginir along the road to Imi (Fig. 1A; Map 1). These hills have outcrops of highly stratified rocks with alternating harder and softer white or grey stone (Fig. 1B), thus forming a striking contrast with the dark red sandstone that crops out on the hillsides of all the surrounding mountains. The topography, geology and observations of associated species in the Acacia-Commiphora woodland are presented in a following section named 'The collecting locality'. A common plant was a conspicuous $2-3.5 \mathrm{~m}$ tall free standing shrub with large inflorescences of pinkish-white flowers with inflorescences and flowers covered by very sticky pink glandular hairs. It was identified in the field as belonging to the family Nyctaginaceae, but when we first visited the site in 2013 it was not possible to ascertain the genus for lack of fruiting material. Searches in the collections at the National Herbarium of Ethiopia, Addis Ababa (ETH) and at the Herbarium of the Royal Botanic Gardens, Kew, UK (K) confirmed that it was indeed a species of Nyctaginaceae, but no material of matching species was found at ETH or K. Further studies of the collected material showed that the plant had large, sphaeroidal, polypantoporate pollen grains (ca. $100 \mu \mathrm{m}$ in diam.), which, according 
to Bittrich and Kühn (1993), suggested that the plant belonged to the tribe Nyctagineae. Lacking the large involucral bracts characteristic of the strictly Neotropical subtribe Nyctagininae, it seemed almost certain that the plant belonged to the subtribe Boerhaviinae Benth. \& Hook. f., of which three genera were known from the Horn of Africa: Boerhavia L., Commicarpus Standl. and Acleisanthes A. Grey (including Selinocarpus A. Gray, according to Levin 2002). Because of the outstanding question of the generic affinity of the plant and the need for fruiting material, it was decided that a field trip in 2014 should go to the same general area and attempt to recollect the plant in fruit.

In Nov., 2014, Sebsebe Demissew and Ib Friis returned to the same locality and were able to recollect the plant with developed anthocarps, as well as to make detailed observations of its habit and habitat and to acquire ethnobotanical information about it from local herdsmen. The fruits were 10ribbed anthocarps with raised glands on the ribs, suggesting that the species belonged to the genus Commicarpus Standl., in spite of its unusual woody habit and striking indumentum on the inflorescences and flowers. On the trip made in 2014 two further species of Commicarpus were found on the same hills: (1) a second much smaller self-supporting woody species with white flowers and anthocarps with regularly placed sessile glands and (2) a spreading subshrub with dark purple flowers and club-shaped anthocarps with a subapical whorl of five stalked glands and scattered sessile glands.

Material with anthocarps of the three species of Commicarpus collected in 2013 and 2014 has now been studied at K, in collaboration with M.G. Gilbert, author of the account of the Nyctaginaceae for the Flora of Ethiopia (Gilbert 2000), and it has been compared with all African and Arabian material of Commicarpus kept at $\mathrm{K}$, as well as some material at ETH, and studied in connection with literature on Nyctaginaceae and Commicarpus (Baker \& Wright 1909; Chiovenda 1929; Bittrich \& Kühn 1993; Douglas \& Manos 2007; Gilbert 2000; Heimerl 1934; Lebrun \& Meikle 
1982; Meikle 1954, 1978, 1979, 1983; Miller 1996; Stannard 1988; Struwig, Siebert \& Klaassen 2011; Thulin 1990, 1993; Whitehouse 1996). No material at ETH and K or description in the literature has been found to match the two shrubby species and they must therefore represent hitherto unknown species, which are described and named here. The third species of Commicarpus (Friis et al. 15464) proved to be best regarded as an extreme form of C. ambiguus Meikle.

\section{The collecting locality: name, position, geology and habitat}

The location and vegetation of the collecting locality of the two new Commicarpus-species is shown on Map 1. A sizeable area around that locality was covered with relatively undisturbed Acacia-Commiphora bushland or woodland, the potential natural vegetation of the region (Friis et al. 2010), and there was no permanent human habitation for at least $10 \mathrm{~km}$ on either side of the places where we collected the three species of Commicarpus. The area was mainly used for grazing cattle, goats, sheep and camels; water was scarce. The nearest permanent habitation, ca. $12 \mathrm{~km}$ to the $\mathrm{W}$ of the collecting locality, was a small, newly established village, which local informants called Beredimtu. Approximately $20 \mathrm{~km}$ to the E was the older village of Idabo, and further $15 \mathrm{~km}$ to the E was the small town of Raaso. Most of these places, except Raaso, are not marked on any map. Five independent individuals or groups of local Oromiffa-speaking herdsmen told us consistently that Lele was the name for the collecting locality, while Somali-speaking herdsmen had no name for it.

The name Lele is mentioned on the sheet no. NB37 (Lago Margarita) in the Italian map series Africa Orientale Italiana in 1:1,000,000, published in 1935 by Istituto Geografico Militare, Firenze (seen at the Centro Studi Erbario Tropicale (FT)). On this map the name is indicated near a peak at ca. $6^{\circ} 42^{\prime} \mathrm{N}, 41^{\circ} 26^{\prime} \mathrm{E}$ in the mountain range named as 'Monti Audo.' This mountain range 
stretches in a NW - SE direction between and parallel with the Weyb and the Wabe Shebelle rivers. The name Lele was also found on sheet no. GSGS NB37 (Lake Margherita) in the British map of Africa series in 1:1,000,000, published in 1946 by the British War Office (seen in the map collection at $\mathrm{K}$ ). On that map the name Lele is indicated near a peak at ca. $6^{\circ} 38^{\prime} \mathrm{N}, 41^{\circ} 23^{\prime} \mathrm{E}$ in the Audo Range. The name Lele is not found on any modern map we have consulted. It is not possible to decide exactly what this 'Lele' refers to. In this paper we will follow the indications of the local Oromo herdsmen and use the name Lele for the hills. More specifically, we will refer to the collecting locality as the Lele Hills, located between $6^{\circ} 33^{\prime}$ and $6^{\circ} 36^{\prime} \mathrm{N}$ and $41^{\circ} 30^{\prime}$ and $41^{\circ} 32.5^{\prime}$ E. Should Lele be a name for a wider area, at least 'Lele Hills' will clearly specify the locality as the isolated hills slightly south of the main Audo Range.

According to Asfawossen Asrat, Geology Department, Addis Ababa University (pers. com.) the Lele Hills consist of hard layers of gypsum and anhydrite intercalated with softer layers of shale and thin layers of dolomites (Fig. 1B). This geological unit is part of the Gorrahei Formation, an evaporite rock deposited during the late Cretaceous. The exact extent of the gypsum outcrops in the Gorrahei Formation at the Lele Hills cannot be estimated from the geological maps we have consulted; Kazmin (1973) has indicated the gypsum outcrops only in restricted areas in the Lele Hills and a few other hills in or near the Audo Range, while Yonas Mulugeta (2010 [2012]) has indicated the presence of gypsum over a much wider area, including formations with gypsum in lower strata that do not appear as outcrops. Gypsum is also found in a number of other geological formations in E Ethiopia, and extensive gypsum outcrops occur in many parts of the Ogaden (Kazmin 1973). However, the gypsum outcrops in the Ogaden are mostly at or below $600 \mathrm{~m}$ a.s.1., as will be discussed at the end of this paper.

The tree stratum of the Acacia-Commiphora woodland on the Lele Hills was dominated by Commiphora guidottii Chiov. (Friis et al. 15467; Fig. 1C \& 1D); the large, fallen leaves of this 
species formed a thin layer of litter on the ground (Fig. 1E). C. guidottii is a tree to ca. $5 \mathrm{~m}$ high and known always to be associated with outcrops of gypsum (Vollesen 1989: 448). It could be observed how the characteristic canopy of $C$. guidottii covered all the north-facing slopes of the Lele Hills, thus indicating that outcrops of gypsum were widespread on the hills (Fig. 1C), but neither in 2013, nor in 2014 we were able to observe the southern side of the hills at close enough range to state if they too had outcrops of gypsum. In the lower strata of the canopy we documented Gyrocarpus hababensis Chiov. (Friis et al. 15469), Acacia edgeworthii T. Anders. (Friis et al. 15470), Platycelyphium voense (Engl.) Wild (Friis et al. 15210), Terminalia orbicularis Engl. \& Diels (Friis et al. 15211) and several smaller species of Commiphora: C. kua (R. Br. ex Royle) Vollesen (Friis et al. 15465), C. kataf(Forssk.) Engl. (Friis et al. 15466), and C. sphaerocarpa Chiov. (Friis et al. 15468). We also documented a few woody lianas, particularly the tuber-based Momordica sessilifolia Cogn. (Friis et al. 15206) and the slender Pergularia daemia (Forssk.) Chiov. (Friis et al. 15227). Scattered shrubs occurred in the lowest stratum, we collected for example Grewia erythraea Schweinf. (Friis et al. 15215), G. pennicillata Chiov. (Friis et al. 15230), G. tenax (Forssk.) Fiori (Friis et al. 15225) and Euphorbia somalensis Pax (Friis et al. 15216). Subshrubs, for example Solanum cordatum Forssk. (Friis et al.15208) and Neuracanthus polyacanthus (Lindau) C.B. Clarke (Friis et al.15209), were found mostly in shade under low shrubs. Apart from scattered populations of the drought-resistant fern Negripteris scioana (Chiov.) Pic. Ser. (Friis et al. 15219) and a few succulents, including species of Aloe L. and Sansevieria Thunberg, the ground was almost completely devoid of herbaceous species (Fig. 1E). This is quite unusual in typical Acacia-Commiphora woodland or bushland, as appears from comparison with the description in Friis et al. (2010: $48-55)$.

The vegetation on red sand and clay in the plains surrounding the Lele Hills was typical AcaciaCommiphora bushland (Fig. 1A) with small and widespread species of Acacia, for example Acacia 
senegal (L.) Willd. and A. mellifera (Vahl) Benth., and similarly small and widespread species of Commiphora, for example C. kua (Friis et al. 15491) and C. africana (A. Rich.) Engl. (Friis et al. 15584); no C. guidottii were seen away from the hills with gypsum.

In 2014, Sebsebe and Friis also found the large, shrubby species of Commicarpus on the gentle slopes of gravel and sand washed down from the Lele Hills towards the large valley and plains W of Raaso. This outlying site for the species was characterised by species of Commiphora other than $C$. guidottii, but from the general topography the soil of these lower slopes must be assumed to have high contents of the minerals present in the rocks of the adjacent hills.

\section{Habit, inflorescence organisation and terminology}

The habit of both the two new species described in this paper is distinctive. They are free standing or self-supporting plants, $0.8-3.5 \mathrm{~m}$ high, and have woody stems with secondary growth, $2-12$ $\mathrm{cm}$ in diam. at the base. Meikle (1978) has pointed out that species of Commicarpus are suffruticose, often partly woody, at least towards the base, with the stems scrambling or climbing, sometimes to a height of $2-\cdot 5 \mathrm{~m}$ or more, while Bittrich \& Kühn (1993) have briefly characterised the species of Commicarpus as subshrubs. We have carried out a survey of the habit of the known species of Commicarpus, both in the in the floristic literature and in the collection of herbarium

material at K. According to our literature survey the species of Commicarpus in Ethiopia and Eritrea were herbaceous perennials, sometimes scandent or subshrubby, or in a few species small shrubs up to $0.5 \mathrm{~m}$ high (Gilbert 2000), in Somalia the species were perennial herbs, woody based perennials, shrublets or subshrubs, sometimes scandent (Thulin 1993), in Arabia the species were annual or perennial herbs, sometimes woody-based (Miller 1996), in tropical E Africa perennial herbs or subshrubs with slender, climbing or trailing stems, often woody towards the base 
(Whitehouse 1996) and in the Flora Zambesiaca area perennial herbs and subshrubs, often with climbing or trailing stems (Stannard 1988). From our survey of herbarium material and from our field experience with a number of species the previously known Arabian and tropical African species of Commicarpus can be regarded as perennial herbs, subshrubs or shrubs, but, if more than ca $0.5 \mathrm{~m}$ high, they are never self-supporting or free standing, always with scrambling or climbing stems from a woody rootstock, and only with limited secondary growth basally. If there is no supporting vegetation the stems would be prostrate or ascending and not more than ca $0.5 \mathrm{~m}$ high. Our two new species significantly widens the range of variation in habit within the genus. Bittrich and Kühn (1993: 475) pointed out that the inflorescences in the Nyctaginaceous tribes which the considered basal in the family are thyrses with more or less reduced dichasial or monochasial partial inflorescences, but this basic structure may be modified in various ways. In the remaining tribes the inflorescences may be thyrsiform or modified further. The two new species of Commicarpus described here both have verticels of well-defined dichasia, which may be reduced to monochasia or just one flower (Fig. 2C, 3A-B, 4B, 5B, 6B). These inflorescences can therefore also be recognised as thyrsiform, that is modified thyrses. In the sections 'Recognition', in the key to species and elsewhere in this paper we have, in agreement with Bittrich and Kühn (1993), used the term thyrsiform for the clearly modified thyrses. This is in contrast to the rest of the species of Commicarpus where the inflorescences are superposed verticels, umbels or capitula (Bittrich and Kühn 1993: 482) in which well-defined dichasia or monochasia were not found in the Commicarpus material at $\mathrm{K}$ and $\mathrm{ETH}$ (see also the drawings or semi-diagrammatic representations of Commicarpus-inflorescences in Meikle 1978: Fig. 1 - 3, 1979: Fig. 1, 1983: Fig. 1; Stannard 1988: Tab. 3; Miller 1996: Fig. 27 - 28 \& Thulin 1990: Fig. 1, 3). We must assume that these inflorescences have also been derived from true thyrses, but this origin is not readily observed. In 
the key to species and elsewhere we have described these inflorescences simply as capitate, umbellate or verticellate, without referring to their assumed origin as thyrses.

For practical reasons we have used the term main peduncle for the axes supporting entire inflorescences, the term rachis for the main axis of the inflorescences from the lowermost verticel to the tip of the inflorescence, the term dichasial peduncle for the axes supporting the dichasia, and the term pedicel for all axes supporting one flower irrespectively of whether that may represent the peduncle of a reduced dichasium or a true pedicel.

The inflorescence of our material of Commicarpus ambiguus (Friis et al. 15464) is also rather unusual, as on closer examination the apparent verticels are not true verticels but rather groups of flowers inserted at the same point on one side of the main axis. There are also solitary flowers along the rachis. These features are pronounced in the material from Lele which was at first thought to represent yet another new taxon, but examination of more material of $C$. ambiguus indicated that the differences in inflorescence morphology were purely quantitative and that there was not a clearcut discontinuity between the new collection from Lele and existing collections of C. ambiguus.

\section{Taxonomy}

Our studies of the three taxa of Commicarpus from Lele Hills conclude that the large and the small shrubs represent new species, here described and named C. macrothammus Friis \& O. Weber and $C$. leleensis Friis \& Sebsebe. See further discussion of taxonomy of under the sections 'Notes' under the respective species.

Commicarpus macrothamnus Friis \& O. Weber sp. nov. Type: Ethiopia, Oromia Regional State, Bale Zone, Raytu Woreda, Lele Hills, lowermost part of NE slope, $127 \mathrm{~km}$ E of Ginir along the road from Ginir to Imi, $6^{\circ} 35.28^{\prime}$ N, $41^{\circ} 33.62^{\prime}$ E, 750 m a.s.1., 13.11.2014, I. Friis, Sebsebe 
Demissew, Wege Abebe, Abubaker Adem and Ermias Getachew 15492 (holotype ETH!; isotypes C!, K! [K000569011]).

Shrub, free standing, up to ca. $3.5 \mathrm{~m}$ tall. Old woody stems forming a trunk up to $12 \mathrm{~cm}$ in diam. at the base of plant (Fig. 3C - D), growth often irregularly twisted and lateral stems may be supported by other woody plants, but main stems almost always upright. Wood pale, with clearly marked growth rings (Fig. 3D). Bark on old stems greyish brown. Persistent main branches initially terete, $3-4 \mathrm{~mm}$ in diam., internodes $5-8 \mathrm{~cm}$ long, nodes sometimes slightly swollen, marked with a faint line between the opposite leaf-bases, bark pale grey to whitish grey, on stems of second growthseason finely puberulous with $0.1-0.3 \mathrm{~mm}$ long hairs that are tipped with minute colourless glandular heads. Most lateral branches deciduous. Leaves strictly opposite: petiole $1.0-3.5 \mathrm{~cm}$ long, canaliculate, slightly puberulous along the edges; lamina slightly glaucous to pale green, broadly ovate to orbicular or obovate, undulate, $4.0-6.5 \times 2.5-6.5 \mathrm{~cm}$, base cuneate to rounded, truncate or subcordate, margin slightly thickened, pale whitish green, usually straight, rarely faintly sinuate, apex rounded, bluntly acute or acuminate, glabrous on both sides, veins $3-6(-7)$ on either side of midvein, not prominent and becoming obscure towards the tip of lamina. Inflorescences terminal on latest season's growth (Fig. 2B - C, 3A - B), deciduous after fruiting, up to 15( - 20) $\mathrm{cm}$ long and $10 \mathrm{~cm}$ wide, paniculate with the ultimate branches verticels of dichasia; main peduncle $3.0-6.0 \mathrm{~cm}$ long, lowermost rachis-internode $2.0-4.0 \mathrm{~cm}$, green, usually flushed slightly purplish pink, upper internodes pink, all parts, including main peduncle, densely beset with ca. $1 \mathrm{~mm}$ long purplish pink sticky glandular hairs; ultimate units of inflorescences 3-flowered dichasia (occasionally reduced to monochasia, rarely to single flowers) on $10-16 \mathrm{~mm}$ long dichasial peduncles; pedicels $8-17 \mathrm{~mm}$ long, slightly elongating up to $20 \mathrm{~mm}$ in fruit (Fig. 2C, 3A-B, 4B). Bracts linear to lanceolate, $4-5(-6) \mathrm{mm}$ long, shortly glandular pilose, caducous. Flower buds 
clavate, dark green and densely glandular pubescent. Perianth (including anthocarp) (15 -) 18 - 20 (-24) mm long; tube $8-10 \mathrm{~mm}$ long, tinged purplish pink and with numerous purplish pink glandular hairs slightly shorter than elsewhere; limb shallowly 5-lobed, $6-8 \mathrm{~mm}$ in diam., $4 \mathrm{~mm}$ long; lobes rounded, slightly retuse, white or very pale pink, veins minutely pubescent (Fig. 4E). Stamens 3, gently curved to almost straight, exserted by $10-15 \mathrm{~mm}$; filaments brownish purple, glabrous, at base fused into a $0.8-1 \mathrm{~mm}$ long tube surrounding the stipe of the ovary; anthers suborbicular in outline, ca. $0.5 \times 0.8 \mathrm{~mm}$. Pollen globular or sphaeroidal, ca. $100 \mu \mathrm{m}$ in diam. (unacetolyzed), pantoporate, spinules of exine not or hardly visible in unacetolyzed pollen. Ovary at anthesis $0.8-1 \times$ ca. $0.5 \mathrm{~mm}$, on $0.8-1 \mathrm{~mm}$ long stipe (Fig. 4F). Style slightly longer than the stamens, exserted by $14-17 \mathrm{~mm}$, glabrous. Stigma globular, ca. $0.3 \mathrm{~mm}$ in diam. Open flowers fragrant. Anthocarp cylindrical to slightly clavate, slightly narrowing at both ends, finely 10 -ribbed, $8-11 \times 2.3-3.0 \mathrm{~mm}$, most glandular hairs fall off during ripening, while $2-4(-6)$ irregularly scattered semi-sessile laterally compressed dark red glands develop along each rib (Fig. 3E - F, 4G). No remains of filaments or the staminal tube was observed in the anthocarp. Fruit a singleseeded achene, ca. $6 \times 2.2 \mathrm{~mm}$, on ca. $1 \mathrm{~mm}$ long stipe, with smooth membranous pericarp, almost filling the inside breadth of the anthocarp (Fig. 4H). Seed with dark brown to almost black membranous testa, filling the pericarp completely. Embryo ca. $5 \times 2 \mathrm{~mm}$, horseshoe-shaped, epidermis dark grey or almost black, with cotyledons partly enveloping the hypocotyl and radicule (Fig. 4J - K). Perisperm white, at first ample, then gradually absorbed during ripening of the seed. Fig. $2-4$.

RECOGNITION. Commicarpus macrothamnus is exceptional among species of Commicarpus by its habit as an erect shrub, almost a small tree, to $3 \frac{1}{2} \mathrm{~m}$ high, it's up to $12 \mathrm{~cm}$ thick and erect woody trunk, and its long purplish pink glandular hairs on the inflorescence-axes, pedicels and lower part 
of perianth with most flowers in distinct dichasia (Fig. 2C, 3B - D, 4B \& D - F). The complex thyrsiform inflorescence-structure of $C$. macrothamnus is most similar to the structure in $C$. leleensis Friis \& Sebsebe. The anthocarps of $C$. macrothamnus are superficially similar to those of C. hieranensis Thulin, but the anthocarps of that species are only $7-8 \mathrm{~mm}$ long, not $8-10 \mathrm{~mm}$ long as in C. macrothamnus, and have two kinds of glands: large dark sessile glands in $1-3$ subapical whorls and smaller irregularly scattered paler glands along the ribs, not, as in $C$. macrothamnus, variable glands irregularly scattered along the ribs.

DISTRIBUTION. Africa: Ethiopia. Commicarpus macrothamnus has been observed north and south of the road between Ginir and Imi (herbarium specimens and sight records by Friis, Weber and Sebsebe Demissew). It appears to be restricted to the hills with gypsum at Lele in Raytu Woreda, Bale Zone, Oromia Regional State; the locality is in the BA floristic region of the Flora of Ethiopia and Eritrea. The collecting localities are listed in Table 1 and indicated on Map 1; sight records are listed in Table 1 (the species was seen almost continuously for a distance of ca. $17 \mathrm{~km}$ along the road). After the initial observations by Friis and Weber in 2013 we assumed that $C$. macrothamnus could possibly occur at other mountains with gypsum deposit at suitable altitudes, and we have therefore modelled the potential distribution of the species with MaxEnt 3.3 (Phillips et al. 2006), using four runs with eight positive presence points and 1000 absence points. For this we used an environmental dataset developed by Paulo van Breugel for modelling Ethiopian vegetation. It was not possible to produce a model based on the occurrence of outcrops of gypsaceous rocks because the two geological maps available to us, Kazmin (1973) and Yonas Mulugeta (2010 [2012]), indicated very different extents of deposits with gypsum, with the former emphasizing outcrops of gypsum and the latter including the presence of gypsum also in lower strata. However, Paulo van Breugel's environmental dataset included the 19 standard bioclimatic 
data layers from Worldclim (Hijmans et al. 2005), altitude from the digital elevation model by CGIAR-CSI (2008), added because it refines the rather crude extrapolated temperature variable from Worldclim, and the first 10 principle components from a Principle Component Analysis made of the 42 edaphic layers ( 7 variables $\times 6$ depths) of the SoilGrids $1 \mathrm{~km}$ dataset (ISRIC 2013). We must assume that the SoilGrids $1 \mathrm{~km}$ dataset to some extent compensated for the lack of a GIS layer indication the presence gypsum, since the soil chemistry recorded in the SoilGrids $1 \mathrm{~km}$ dataset is influenced by the underlying substrate, from which the soil is partly derived. The model output is shown in Map 2. According to this model the main potential distribution area is located along the Audo Range, whilst smaller potential areas with much lower suitability are sparsely distributed to the SW in association with unnamed mountain ranges between the Genale and the Weyb rivers and the mountains to the NE on either side of the Wabe Shebelle River north of Imi.

From the data produced for Map. 2 we extracted points with a suitability higher than 0.5 ; the most peripheral of these points, listed in Table 1, form a polygon with an area of ca. $24,500 \mathrm{~km}^{2}$. This we assume to be the absolutely largest potential distribution of Commicarpus macrothamnus, and in 2014 we searched for the species within this area. The search was unsuccessful in all other areas than the Lele Hills. We looked particularly for C. macrothamnus on hills associated with the Audo Range (see Map 1; the red outlines indicate areas along the Audo Range where the new species of Commicarpus were predicted to occur but not found). After the modelling and our field studies in 2014 we find it most probable that C. macrothamnus is restricted to the gypsum outcrop above 750 $\mathrm{m}$ at Lele and possibly to a very few other hills of similar height with gypsum outcrops. The most probable additional localities were east of the Wabe Shebelle river north of Imi, but we could not visit this area in 2013 or 2014. Our model in Map 2 represents altitudes lower than 500-600 m with black, suggesting that the species is highly unlikely to occur at these altitudes. 
SPECIMENS EXAMINED. ETHIOPIA. Oromia Regional State, Bale Zone: Lele Hills, lower part of $\mathrm{N}$ slope $\mathrm{S}$ of the road from Ginir to Imi, $114 \mathrm{~km}$ E of Ginir along the road, $6^{\circ} 36.16^{\prime} \mathrm{N}, 41^{\circ}$ 31.07' E, 900 m a.s.1., 14.12.2013, I. Friis, Odile Weber, Wege Abebe, Abubaker Adem and Ermias Getachew 15223 (C!, ETH!, K!). Lele Hills, lower part of NW S of the road from Ginir to Imi, 110 $\mathrm{km}$ E of Ginir along the road, 6 $36.13^{\prime} \mathrm{N}, 4^{\circ} 31.06^{\prime} \mathrm{E}, 875 \mathrm{~m}$ a.s.1., 11.11.2014, I. Friis, Sebsebe Demissew, Wege Abebe, Abubaker Adem and Ermias Getachew 15462 (C!, ETH!, K!). Lele Hills, lowermost part NE slope S of the road from Ginir to Imi, $127 \mathrm{~km}$ E of Ginir along the road, $6^{\circ}$ 35.28' N, $41^{\circ} 33.62^{\prime}$ E, 750 m a.s.1., 13.11.2014, I. Friis, Sebsebe Demissew, Wege Abebe, Abubaker Adem and Ermias Getachew 15492 (holotype ETH!; isotypes C!, K! [K000569011]).

HABITAT. Acacia-Commiphora bushland on grey soil derived from and at lowermost altitudes washed down from rocks with gypsum. Commiphora guidottii Chiov. dominant in the tree-stratum. Hardly any ground cover. 750 - $900 \mathrm{~m}$ a.s.1. See also the section 'The collecting locality'. Fig. 1A E.

CONSERVATION STATUS. Locally abundant (some 500 - 1000 individuals seen along the ca. $17 \mathrm{~km}$ stretch of road through the area with gypsum outcrops). Some plants were mature with thick trunk and up to $3.5 \mathrm{~m}$ high, others were young. Although no new seedlings were observed we must assume that there is reproduction. The observed population (see Table 1) has an Extent of Occurrence (EOO) of $7.3 \mathrm{~km}^{2}$ with an Area of Occupancy (AOO) of $16 \mathrm{~km}^{2}$ (cell size $2 \mathrm{~km}^{2}$ ). The EOO and AOO were calculated using the GeoCAT tool (Bachman et al. 2011). Under criterion B the EOO is far below the threshold of Critically Endangered (CR), and the AOO is far below the threshold of Endangered (EN). It is likely that Commicarpus macrothammus has a wider range in the Lele Hills, possibly throughout the hills (Fig. 1A) If the peripheral points of the hills are included with the observed occurrences (see estimated records in Table 1) then the EOO increases 
to ca. $30 \mathrm{~km}^{2}$, still below the thresholds of CR. A recent threat to the habitat at the Lele Hills has been the construction of the new road between Ginir and Imi, which might facilitate settlement, but currently, the area is sparsely populated and only occasionally visited by herdsmen.

On the hydrogeological map of Yonas Mulugeta (2010 [2012]) the area of and around the Lele Hills is indicated as 'Formation with essentially no ground water resources.' Lack of ground water makes it difficult or impossible to drill wells for increased grazing, but reservoirs for gathering rain water were being established at the new village called Beredimtu and in uninhabited areas E of the Lele Hills, creating the possibility for more intense grazing and possibly human settlements. Given the restricted known distribution and the low level of ongoing threats, Commicarpus macrothamnus should be regarded as Vulnerable (VU) according to criterion D2 (IUCN 2012). CR or EN according to criteria $\mathrm{B} 1 \mathrm{ab}(\mathrm{i}-\mathrm{v})$ or $\mathrm{B} 2 \mathrm{ab}(\mathrm{i}-\mathrm{v})$ are unlikely to be justified given the lack of ongoing threats to the habitats at the Lele Hills.

In spite of the intensive search during our field work in 2014 it cannot completely be ruled out that C. macrothamnus has a wider range associated with other outcrops of gypsum and within the area with localities with a suitability higher than 0.5 , but that does not seem likely. See discussion of the potential distribution in the section 'Distribution' above and the section 'Gypsophily in Nyctaginaceae and gypsum endemics in Ethiopia' at the end of this paper.

PHENOLOGY. Flowering Nov - Dec. Fruits observed in one specimen in late Nov at $750 \mathrm{~m}$ a.s.1. after an unusually wet and long rainy season.

ETYMOLOGY. The specific epithet is a Latinized substantive derived from Greek: $\mu \alpha \kappa \rho о-$ $($ macro $)=$ big, large, and $\theta \alpha \dot{\mu} \mu \nu o \varsigma($ thamnos $)=$ shrub. 
VERNACULAR NAME. KONTOM, name given independently by two older and one young Oromiffa-speaking informant through the intermediary of our guide Abubaker Atem. One very young Oromiffa-speaking informant called the plant GUBI. Two independent Somali-speaking informants did not recognise the plant and had no name for it.

USES. According to the Oromiffa-speaking informants the plant is eaten by all animals grazed in the area, camels, cows, goats and sheep. One informant claimed that cows should not eat it, as they might develop stomach trouble.

NOTES. Commicarpus macrothamnus is a tall shrub or a small tree with thick woody stems developed during continued secondary growth with well-developed growth-rings. The habit, discussed in the section 'Habit, inflorescence organisation and terminology', is so unusual that we at first doubted that the species should be placed in that genus. Meikle (1978), who, after having revised the entire genus as known then, pointed out that Commicarpus is readily recognisable by anthocarps studded with large, viscid, sessile or stipitate glands and that this striking diagnostic

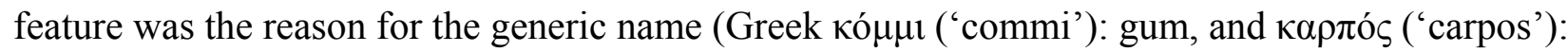
fruit). Viscid, sessile glands also develop in Commicarpus macrothamnus, although irregularly and quite late in the development of the anthocarp.

Commicarpus leleensis Friis \& Sebsebe sp. nov. Type: Ethiopia, Oromia Regional State, Bale Zone, Raytu Wereda, Lele Hills, N slope S of the road from Ginir to Imi, $110 \mathrm{~km}$ E of Ginir along the road, $6^{\circ} 36.13^{\prime} \mathrm{N}, 41^{\circ} 31.06 '$ E, 875 m a.s.1., 11.11.2014, Friis, Sebsebe Demissew, Wege Abebe, Ermias Getachew \& Abubaker Adem 15463 (holotype ETH!; isotypes C!, K! [K0005690010]). 
Shrub, rounded, self-supporting, densely branched, to ca. 0.8 (- 1) m tall (Fig. 5A). Old woody stems up to ca. $2 \mathrm{~cm}$ in diam., with greyish to greyish white bark. Persistent main branches initially terete, $3-5 \mathrm{~mm}$ in diam., rapidly glabrescent. Leaves strictly opposite, glabrous: petiole $1.5-2.2$ $\mathrm{cm}$ long, lamina ovate to obovate, $3.0-5.4 \times 2.0-4.0 \mathrm{~cm}$, base cuneate, margin slightly sinuate, apex acute to slightly retuse, veins 3 on each side of midvein, becoming obscure towards tip of lamina (Fig. 6A). Inflorescences terminal, up to $20 \mathrm{~cm}$ long and $15 \mathrm{~cm}$ wide, paniculate, branches with 2( - 3) verticels of dichasia or monochasia, these sometimes one-flowered, axes all green; main peduncle to $6.0 \mathrm{~cm}$ long, glabrous; main rachis zigzag with 1 or 2 branches at each node, lowermost internode to $6.0 \mathrm{~cm}$ long, upper rachis with successively shorter internodes, all inflorescence axes with short glandular hairs up to ca. $0.2 \mathrm{~mm}$ long, sparser and up to $0.4 \mathrm{~mm}$ long on upper branches; ultimate units of inflorescences usually 3-flowered dichasia on $9-24 \mathrm{~mm}$ long dichasial peduncles, but sometimes monochasia or single flowers; pedicels $5-10 \mathrm{~mm}$ long, sparsely glandular, elongating to $6-12 \mathrm{~mm}$ in fruit (Fig. 5B, 6B). Bracts lanceolate, $2.5-4 \mathrm{~mm}$ long, almost glabrous, very rapidly deciduous (Fig. 6C). Flower buds clavate, green and finely puberulous (Fig. 6D). Perianth (including anthocarp) 8-12 mm long, green except for limb, minutely glandular; tube $4-5 \mathrm{~mm}$ long, almost glabrous or finely puberulous; limb white or very pale pink, drying pinkish, $3-4 \mathrm{~mm}$ long, funnel-shaped with spreading lobes, $8-10 \mathrm{~mm}$ in diam.; lobes rounded, slightly retuse and minutely cuspidate, veins at the base of limb minutely puberulous, otherwise glabrous (Fig. 6E). Stamens 3, straight to gently curved, exserted for $6-7$ $\mathrm{mm}$, slightly shorter than style, at base fused into a $1.1-1.3 \mathrm{~mm}$ long tube surrounding the stipe of the ovary; filaments glabrous, purplish; anthers $0.3-0.4 \times$ ca. $0.5 \mathrm{~mm}$. Pollen globular or sphaeroidal, ca. $75 \mu \mathrm{m}$ in diam. (unacetolyzed), pantoporate, spinules of exine not or hardly visible in unacetolyzed pollen. Ovary at anthesis $1.2-1.5 \times$ ca. $0.8 \mathrm{~mm}$, on $1.2-1.4 \mathrm{~mm}$ long stipe (Fig. 6F). Style approximately as long as the stamens, exserted for $5-6 \mathrm{~mm}$. Stigma globose, ca. $0.4 \mathrm{~mm}$ 
in diam. Anthocarp fusiform, 10-ribbed, ca. $10 \times 2.5 \mathrm{~mm}$, with $(4-) 5-7$ pale sessile glands along each rib (Fig. 5B, 6G). Glands start developing at the apex of the anthocarp in regular whorls and develop more irregularly towards the base. No remains of filaments or staminal tube was observed in the anthocarp. Fruit a single-seeded achene, ca. $6 \times 1.5 \mathrm{~mm}$, on ca. $1.5 \mathrm{~mm}$ long stipe, with striped membranous pericarp, almost filling the inside breadth of the anthocarp (Fig. 6H). Seed with grey membranous testa, filling the pericarp completely. Embryo ca. $5.5 \times 1.2 \mathrm{~mm}$, horseshoeshaped, with grey, mottled or blackish epidermis, cotyledons partly enveloping the hypocotyl and radicle (Fig. $6 \mathrm{~J}-\mathrm{K}$ ). Perisperm white, at first ample, then gradually absorbed during ripening of the seed. Fig. $5-6$.

RECOGNITION. Commicarpus leleensis resembles $C$. macrothamnus in its shrubby habit, in the thyrsiform inflorescence structure, with dichasia often being the ultimate inflorescence-units and in seed and endosperm morphology. It differs by being a much smaller shrub up to $0.8(-1) \mathrm{m}$ high with a more complex paniculate inflorescence, in which the branches carry verticels of dichasia or monochasia which more often than in C. macrothamnus is replaced by single flowers, by the lack of the long pink glandular hairs on the inflorescence and perianth, by the much shorter and paler perianth tube and by the more regular and well-defined glands on the mature anthocarp. C. leleensis is somewhat similar to C. plumbagineus, which also has white, rarely pale pink flowers with three stamens, but $C$. plumbagineus differs in being a trailing and scandent subshrub with the irregular inflorescence lacking dichasia, and having two irregular subapical whorls of stalked or subsessile glands on the anthocarp.

DISTRIBUTION. Africa: Ethiopia. The observed distribution is restricted to the Lele hills. The exact collecting locality is marked by the middle blue bird-eye dot in Map 1. The considerations 
discussed under Commicarpus macrothamnus about the possible occurrence of the species also apply to C. leleensis.

SPECIMENS EXAMINED. ETHIOPIA. Ethiopia, Oromia Regional State, Bale Zone, Raytu Wereda, Lele Hills, N slope S of the road from Ginir to Imi, $110 \mathrm{~km}$ E of Ginir along the road, $6^{\circ}$ 36.13' N, $41^{\circ} 31.06 '$ E, 875 m a.s.1., 11.11.2014, Friis, Sebsebe Demissew, Wege Abebe, Ermias Getachew \& Abubaker Adem 15463 (holotype ETH!; isotypes C!, K! [K000569010]).

HABITAT. Acacia-Commiphora bushland on rocks with a thin layer of grey soil derived from rocks with gypsum. Commiphora guidottii Chiov. dominant in the tree-stratum. Hardly any ground cover. Ca. $875 \mathrm{~m}$ a.s.1. See also the section 'The collecting locality'. Fig. 1A - E.

CONSERVATION STATUS. Commicarpus leleensis is locally rare and only known from the type locality. It was collected in the middle of the distribution of C. macrothamnus and the same discussion about the limited threats to the habitat in this area as under this species applies. Commicarpus leleensis could at the very least be listed as VU under criterion D2, like $C$. macrothamnus. Since C. leleensis is absent from localities where C. macrothamnus has been observed, we are also lead to conclude that it is more at risk than that species. It was not possible to establish if the population at the type locality consists of less than 50 mature individuals, the threshold number for the category Critically Endangered (CR), but it is very small. Further research would be needed to confirm that that the species is Critically Endangered based on criterion D. Pending further information, it should be listed as Data Deficient (DD).

PHENOLOGY. Flowering and fruiting in Nov. 
ETYMOLOGY. The specific epithet is derived from the place name Lele, used by the local Oromiffa-speaking herdsmen for the locality where the plant was found.

VERNACULAR NAME. None recorded.

USES. None recorded.

NOTES. Most of the discussion of habit and inflorescence structure in the section 'Habit, inflorescence organisation and terminology' also applies here, but Commicarpus leleensis is much smaller and less prominently woody than C. macrothamnus. The differences between C. leleensis and the probably closest related species, C. macrothamnus, has been pointed out in the section 'Recognition'. C. leleensis may resemble some forms of the also white flowered C. plumbagineus occurring on gypsum, for example Thulin \& Warfa 4654, collected between El Bur and El Dere in Somalia ( $4^{\circ} 38^{\prime} \mathrm{N}, 46^{\circ} 37^{\prime} \mathrm{E}, 150 \mathrm{~m}$ a.s.1.), but in C. plumbagineus the leafbases are trucate or more often subcordate, the ultimate parts of the inflorescences verticels or umbels (in which the number of flowers may vary from 10 to three, two or one) and the ring of subapical glands on the anthocarp are always stalked or subsessile. C. leleensis has consistently cuneate leafbases, the ultimate parts of the inflorescences are more or less reduced dichasia, and the glands of the anthocarps are all similar and sessile.

\section{Key to the species of Commicarpus on the Horn of Africa}

The description of two new species necessitates an amended key to all the species of Commicarpus known from the Horn of Africa. The species numbers in the most recent flora accounts of the Horn are indicated like this: Thulin (1993) as FS x, Gilbert (2000) as FEE y. 
1. Inflorescence thyrsiform with at least some flowers in the ultimate parts of the inflorescences in well-defined dichasia; plants free standing or self-supporting, $0.8-3.5 \mathrm{~m}$ high. 2

- Inflorescence capitate, umbellate or with flowers in verticels, very rarely with flowers in the ultimate parts of the inflorescences in reduced 2-flowered umbels; plants less than ca. $0.5 \mathrm{~m}$ high, if more then clearly supported by surrounding vegetation.

2. Robust free standing shrub, up to $3 \frac{1}{2} \mathrm{~m}$ high, main stems $4-12 \mathrm{~cm}$ in diam. with obvious secondary thickening; inflorescence densely beset with conspicuous pink glandular hairs ca. 1 mm long; perianth (including anthocarp) $(15-) 18-20(-24) \mathrm{mm}$ long ...... C. macrothamnus

-. Broad self-supporting shrub $0.8(-1) \mathrm{m}$ high, main stems up to $2 \mathrm{~cm}$ thick at base; inflorescence axes with inconspicuous pale glandular hairs up to $0.4 \mathrm{~mm}$ long, glabrescent; perianth (including anthocarp) $8-12 \mathrm{~mm}$ long.... C. leleensis

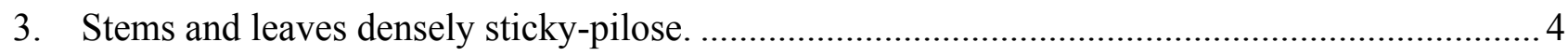

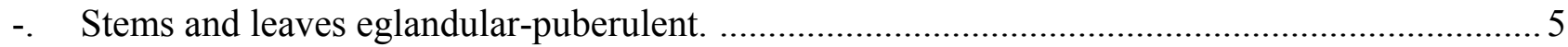

4. Anthocarp with prominent sessile glands all over; pedicel 9-15 mm long; perianth limb 7.5$11 \mathrm{~mm}$. FS 2, FEE 2. C. grandiflorus

-. Anthocarp with a subapical whorl of 3 shortly stalked or subsessile glands plus scattered smaller sessile glands; pedicels up to $10 \mathrm{~mm}$; perianth limb ca. $5 \mathrm{~mm}$ FS 3. C. stenocarpus

5. Leaves reniform, broader than long; inflorescences shorter than subtending leaves, peduncle up to $5 \mathrm{~mm}$ long, shorter than pedicels. .FS 9, FEE 6. C. reniformis

- Leaves ovate, often acute to acuminate, longer than broad; inflorescences longer than subtending leaves, peduncle many times longer than pedicels.

6. Stems prostrate, flowers in dense head-like umbels on stout erect peduncles; stamens 5 or 6; anthocarp with stalked glands only, sessile glands obscure to virtually absent 
- Stems erect, ascending or scandent; flowers in lax terminal panicles, often irregularly branched;'stamens (1-) 2-4; anthocarp with both stalked and clearly defined sessile or subsessile glands

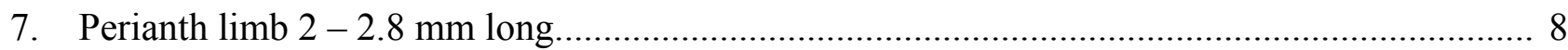

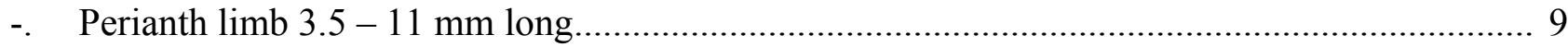

8. Inflorescence with (2-) 3 or $4(-5)$ verticels; perianth pink, mauve or purple

FS 12, FEE 9. C. helenae

- Inflorescence with pedunculate umbels only; perianth white or very pale pink

.FS 7. C. parviflorus

9. Anthocarp with uniformly sessile or subsessile glands; leaf blade prominently sinuate to distinctly lobed FS 5, FEE 4. C. sinuatus

- Anthocarp with 1-3 subapical whorl(s) of conspicuously stalked to subsessile glands which differ from the sessile or subsessile glands on the rest of the anthocarp; leaf blade entire 10

10. Perianth limb $7-11 \mathrm{~mm}$ long, white or mauve.....

-. $\quad$ Perianth limb $3.5-6 \mathrm{~mm}$ long, pink, red or purple 12

11. Perianth white; inflorescence an irregular panicle of umbels and verticels; anthocarp with two whorls of stalked to subsessile glands ..FS 4, FEE 3. C. plumbagineus

-. Perianth mauve; inflorescence a panicle of umbels; anthocarp with a single whorl of c. 5 stalked glands FS 8. C. ramosissimus

12. Flowers in umbels; perianth limb $4-6 \mathrm{~mm}$, hairy. FS 6, FEE 5. C. mistus

-. Flowers in (1 -) $2-4$ (-5) verticels; perianth limb $3.5-4 \mathrm{~mm}$, glabrous. 13

13. Anthocarp with single subapical whorl of 5 stalked glands; internodes of rachis longer than pedicels FS 11, FEE 7. C. ambiguus

- Anthocarp with 1 - 3 subapical whorls of sessile glands; internodes of rachis shorter than to slightly longer than pedicels FS 10, FEE 8. C. hiranensis 


\section{Gypsophily in the Nyctaginaceae and gypsum endemics in Ethiopia}

The discovery of two new species of Commicarpus on rocks with high contents of gypsum, as well as the presence on the gypsum at Lele of C. ambiguus Meikle, makes it worthwhile to refer to Douglas and Manos (2007), who have discussed the character gypsophily among the xerophytic species of North American Nyctaginaceae and reconstructed its distribution by phylogenetic analyses using molecular and morphological data. Douglas and Manos (loc. cit.) found that gypsum-tolerant species are widely dispersed in Nyctaginaceae, particularly in a clade including Boerhavia L. (almost pantropical), Commicarpus (almost pantropical, but mainly African), Acleisanthes A. Gray (Neotropical, but with one gypsophilous species, A. somaliensis (Chiov.) R.A. Levin, in Somalia and possibly also in E Ethiopia (Gilbert 2000)), Nyctaginia Choisy (N America), Annulocaulis Standl. (N America), Cyphomeris Standl. (N America), Allionia L. (N and S America), Mirabilis L. (almost exclusively American) and Abronia Juss. (N America). Douglas and Manos concluded that they cannot know the gypsum tolerance of basal taxa of that clade, but their studies indicate that there are at least four instances of strong gypsophily evolving in the family, and that strongly gypsophilous species frequently have closely related non-gypsophilic species. Therefore they suggested that there is a 'tendency' that gypsophily may evolve repeatedly and scattered in the family and that there is a high level of homoplasy with regard to that character (as well as to a number of other characters) in the Nyctaginaceae. The two new species of Commicarpus from the Lele Hills agree with these suggestions, as most of the twelve previously known species of Commicarpus in the Horn of Africa are not strikingly gypsophilous, while the single species of Acleisanthes (Selinocarpus), A. somalensis, is restricted to gypsum (Thulin 1993: 171 - 175; Gilbert 2000: 270 - 273). 
The eastern Ethiopian lowlands, particularly the Ogaden below $600 \mathrm{~m}$ a.s.l., are rich in gypsum outcrops (Kazmin 1973; Yonas Mulugeta 2010 [2012]) and the Ogaden is known for its local endemics associated with special geological structures such as sandstone, limestone or gypsum outcrops (Thulin 2009a, 2009b, 2011). Many of the Ogaden gypsum endemics have a very restricted distribution: "The potential to find new local endemic species [in the Ogaden] is high, particularly on gypsum outcrops." (Thulin 2011: 92). From the range of examples cited in the following this seems to be particularly true for species restricted to altitudes below $600 \mathrm{~m}$. Out of four new narrowly endemic species of Euphorbia described from the Ogaden by Thulin (2009a) two, E. piceoides Thulin and E. suborbicularis Thulin, were associated with gypsum formations of restricted range and at altitudes at ca. $600 \mathrm{~m}$ a.s.l. or below. One new species of Ceropegia, $C$. gypsophila Thulin, was described from a single gypsum hill east of Kebri Dehar in SE Ethiopia at ca. 550 m a.s.1. (Thulin 2009b). Blepharis gypsophila Thulin \& Vollesen (2015) was described from open Acacia-Commiphora bushland at ca. $300 \mathrm{~m}$ a.s.1. on gypsum close to Kelafo in SE Ethiopia, near the border with Somalia, and not far from the type locality of Acacia pseudonigrescens Brenan \& J. Ross, which has only been recorded from a gypsum hillock near Mustahil at ca. $300 \mathrm{~m}$ a.s.l. (Ross 1974).

However, some endemic species associated with gypsum are more widespread. Commiphora guidottii, which is dominant in the vegetation on Lele Hills, occurs on gypsum hills both in S Ethiopia and in adjacent parts of Somalia (Vollesen 1989). The endemic Acacia fumosa Thulin occurred in the Ogaden over an area of at least $8000 \mathrm{~km}^{2}$ and was found both on limestone and gypsum (Thulin 2008).

So far no narrowly endemic species associated with gypsum other than the two new species of Commicarpus described in this paper has been found in the area between Ginir and Imi and at altitudes higher than $600 \mathrm{~m}$ a.s.1. However, Euphorbia piscidermis M. Gilbert, a species presumably 
restricted to low gypsum-bearing ridges near Degeh Bur ca. $140 \mathrm{~km} \mathrm{SE} \mathrm{of} \mathrm{Jijiga,} \mathrm{is} \mathrm{found} \mathrm{at} 1000$ $1050 \mathrm{~m}$ a.s.1. (Gilbert 1973, 1995: 340) and may be another rare example of Ethiopian gypsum endemics found at relatively high altitudes.

\section{Acknowledgements}

The authors are indebted to the Carlsberg Foundation for continued support to the study of the flora and vegetation of Ethiopia, including the field trips to the Bale Zone in 2013 and 2014. The Bentham-Moxon Trust of the Royal Botanic Gardens, Kew, is thanked for supporting Odile Weber's participation in the field work in 2013. The travel companions in 2013 and 2014, Wege Abebe, technical assistant at ETH, Abubaker Adem, guide from Dinshu, and Ermias Getachew, driver at the College of Natural Science, Addis Ababa University, are thanked for excellent help and company in the field. The herbarium ETH and the College of Natural Science, Addis Ababa University, are acknowledged for logistic support during and after the field work. We also wish to thank Paulo van Breugel for the dataset used in the modelling of species distribution and Victoria Cicely Gordon Friis for preparing the drawings for Fig. 4 and 6, as well as for her help with the dissections, analyses and descriptions of anthocarps, fruits, seeds and embryos of both species. 


\section{References}

Bachman, S., Moat, J., Hill, A., de la Torre \& Scott, B. (2011) Supporting Red List threat assessments with GeoCAT: geospatial conservation assessment tool. ZooKeys 150: 117 - 126 . DOI: $10.3897 /$ zookeys.150.2109. The software used in this study was an updated version available at http://geocat.kew.org/; addressed in May, 2015.

Baker, J. G. \& Wright, C. H. (1909). Nyctagineae. In: W. T. Thiselton-Dyer (ed.), Flora of tropical Africa. Vol. 6,1: 1-9. Reeve, London.

Bittrich, V. \& Kühn, U. (1993). Nyctaginaceae. In K. Kubitzki, J.G. Rohwer \& V. Bittrich (eds.), The families and genera of vascular plants, Vol. 2: 473 - 486. Springer-Verlag, Berlin.

Chiovenda, E. (1929). Flora Somala. Sindacato italiano arti grafiche, Roma.

CGIAR-CSI (2008). CGIAR-CSI SRTM 90 m DEM Digital Elevation Database. Version 4. CGIAR Consortium for Spatial Information (CGIAR-CSI). http://srtm.csi.cgiar.org/ Index.asp (Accessed 30 April 2014).

Douglas, N. A. \& Manos, P. S. (2007). Molecular phylogeny of Nyctaginaceae: taxonomy, biogeography and characters associated with a radiation of xerophytic genera in North America. Amer. J. Bot. 96: $856-872$.

Friis, I., Sebsebe Demissew \& van Breugel, P. (2010). Atlas of the Potential Vegetation of Ethiopia. Biol. Skr. 58: $1-308$.

Gilbert, M. G. (1973). A New Species of Euphorbia from the Ogaden, Ethiopia. Kew Bull. 28(3): $437-440$. 
Gilbert, M. G. (1995). 85. Euphorbiaceae. In: S. Edwards, Mesfin Tadesse, \& I. Hedberg (eds.), Flora of Ethiopia and Eritrea, Vol. 2,2. Canellaceae to Euphorbiaceae:265 - 380. Addis Ababa: The National Herbarium, Addis Ababa, and Department of Systematic Botany, Uppsala.

Gilbert, M. G. (2000). 34. Nyctaginaceae. In: S. Edwards, Mesfin Tadesse, Sebsebe Demissew \& I. Hedberg (eds.), Flora of Ethiopia and Eritrea, Vol. 2,1. Magnoliaceae to Flacourtiaceae: 264 - 273. Addis Ababa: The National Herbarium, Addis Ababa, and Department of Systematic Botany, Uppsala.

Heimerl, A. (1934). Nyctaginaceae. In: A. Engler and K. Prantl (eds), Die Natürlichen Pflanzenfamilien, 2nd edition, 16c: 86 - 134. Engelmann, Leipzig.

Hijmans, R. J., Cameron, S. E., Parra, J. L., Jones, P. G. \& Jarvis, A. (2005). Very high resolution interpolated climate surfaces for global land areas. Int. J. Climatol. 25: 1965 - 1978.

ISRIC (2013). SoilGrids: an automated system for global soil mapping. ISRIC - World Soil Information. http://www.isric.org/content/soilgrids (Accessed 30 April 2014).

IUCN (2012). IUCN Red List Categories and Criteria. Version 3.1. Second edition. Gland \& Cambridge.

Kazmin, V. (1973). Geological Map of Ethiopia. Geological Survey of Ethiopia, Ministry of Mines, Addis Ababa.

Lebrun, J.-P. \& Meikle, R. D. (1982). Un Commicarpus (Nyctaginaceae) noveau du Tchad meridional. Bull. Mus. natn. Hist. nat. Paris IV,4: $41-42$.

Levin, R. A. (2002). Taxonomic Status of Acleisanthes, Selinocarpus, and Ammocodon (Nyctaginaceae). Novon 12: 58-63. 
Meikle, R. D. (1954). Nyctaginaceae. In: J. Hutchinson, J. M. Dalziel \& R. W. J. Keay (eds.), Flora of West tropical Africa, 2. Edition, 1,1: 176 - 178. Crown Agents for Oversea Governments and Administrations, London.

Meikle, R. D. (1978). A key to Commicarpus. Notes Roy. Bot. Gard. Edinburgh 36: 235 - 249.

Meikle, R. D. 1979. Supplementary notes on Commicarpus (Nyctaginaceae). Kew Bull. 34: 341 343.

Meikle, R. D. (1983). Additional notes on Commicarpus (Nyctaginaceae). Kew Bull. 38: 481 - 484.

Miller, A. G. (1996). Fam. 33. Nyctaginaceae. In: A.G. Miller \& T. Cope (eds.), Flora of the Arabian Peninsula and Socotra, Vol. 1: 143 - 155. Edinburgh University Press, Edinburgh.

Phillips, S. J., Anderson, R. P. \& Schapire, R. E. (2006). Maximum entropy modelling of species geographic distributions. Ecological Modelling 190: 231 - 259.

Ross, J. H. (1974). Notes on miscellaneous Acacia species from Tropical Africa. Bothalia 11,3: 291-294.

Stannard, B. L. (1988). Nyctaginaceae. In: E. Launert (ed.), Flora Zambesiaca 9,1: 12 - 28. Halesworth Press, London.

Struwig, M., Siebert, S.J.\& Klaassen, E.S. (2011). Notes on African Plants: Nyctaginaceae. Notes on Commicarpus in Southern Africa, including a new record for Namibia. Bothalia 41,2: 289 - 326.

Thulin, M. (1990). Four new species of Commicarpus (Nyctaginaceae) from NE tropical Africa. Nord. J. Bot. 10: $403-409$.

Thulin, M. (1993). 41. Nyctaginaceae. In: M. Thulin (ed.), Flora of Somalia, Vol. 1: 168 - 175. Royal Botanic Gardens, Kew. 
Thulin, M. (2008). Acacia fumosa sp. nov. (Fabaceae) from eastern Ethiopia. Nordic J. Bot. 25: 272 $-274$.

Thulin, M. (2009a). New species of Euphorbia (Euphorbiaceae) from eastern Ethiopia. Kew Bull. 64: $469-476$.

Thulin, M. (2009b). New species of Caralluma and Ceropegia (Apocynaceae: AsclepiadoideaeCeropegieae) from eastern Ethiopia. Kew Bull. 64: 477 - 483.

Thulin, M. (2011). Ogaden - still terra incognita? In: I. Hedberg (ed.), The Ethiopian Flora Project 1980 - 2009 - exploration, collaboration, inspiration (Symbolae Botanicae - Acta Universitatis Upsaliensis 35.2): 79 93. University of Uppsala, Uppsala.

Thulin, M. \& Vollesen, K. (2015). Blepharis gypsophila (Acanthaceae), a new species from Ethiopia. Kew Bull. 70: Paper 26, pp. 1 - 3.

Vollesen, K. (1989). 123. Burseraceae. In: I. Hedberg \& S. Edwards (eds.), Flora of Ethiopia, vol. 3: 442 - 478. Universities of Addis Ababa and Asmara, Ethiopia, and University of Uppsala, Sweden.

Whitehouse, C. (1996). Nyctaginaceae. In: R. M. Polhill (ed.), Flora of Tropical East Africa, Nyctaginaceae: 1 - 20. A. A. Balkema, Rotterdam.

Yonas Mulugeta. (2010 [2012]). Hydrogeological Map of Ethiopia. 1:250000. Sheet: Megalo NB 37-8. Printed by the Geological Survey of Ethiopia in cooperation with the Czech Republic Development Cooperation. 
Tables

Table 1. Observed, estimated and modelled distribution points of Commicarpus macrothamnus used to calculate the Extent of occurrence (EOO) and Area of occupancy (AOO). Latitudes and longitudes are indicated in decimal degrees. See main text for further information.

\begin{tabular}{|c|c|c|c|c|}
\hline Basis of Record & Latitude & Longitude & EOO in $\mathrm{km}^{2}$ & $\mathrm{AOO}$ in $\mathrm{km} 2$ \\
\hline Herbarium record & 6.603 & 41.518 & \multirow{12}{*}{7.3} & \multirow{12}{*}{16} \\
\hline Herbarium record & 6.602 & 41.518 & & \\
\hline Herbarium record & 6.588 & 41.56 & & \\
\hline Sight record & 6.602 & 41.499 & & \\
\hline Sight record & 6.600 & 41.501 & & \\
\hline Sight record & 6.599 & 41.504 & & \\
\hline Sight record & 6.599 & 41.507 & & \\
\hline Sight record & 6.594 & 41.509 & & \\
\hline Sight record & 6.599 & 41.515 & & \\
\hline Sight record & 6.602 & 41.517 & & \\
\hline Sight record & 6.602 & 41.526 & & \\
\hline Sight record & 6.608 & 41.532 & & \\
\hline Estimate & 6.595 & 41.498 & \multirow{5}{*}{$30^{*}$} & \multirow{5}{*}{ na } \\
\hline Estimate & 6.584 & 41.488 & & \\
\hline Estimate & 6.559 & 41.499 & & \\
\hline Estimate & 6.554 & 41.515 & & \\
\hline Estimate & 6.579 & 41.550 & & \\
\hline MaxEnt model & 7.450 & 41.960 & \multirow{6}{*}{24548} & \multirow{6}{*}{ na } \\
\hline MaxEnt model & 7.190 & 42.510 & & \\
\hline MaxEnt model & 5.850 & 42.180 & & \\
\hline MaxEnt model & 5.490 & 41.030 & & \\
\hline MaxEnt model & 6.140 & 40.850 & & \\
\hline MaxEnt model & 6.860 & 41.240 & & \\
\hline
\end{tabular}

* based on the observed records supplemented by the estimated distribution in the Lele Hills. 


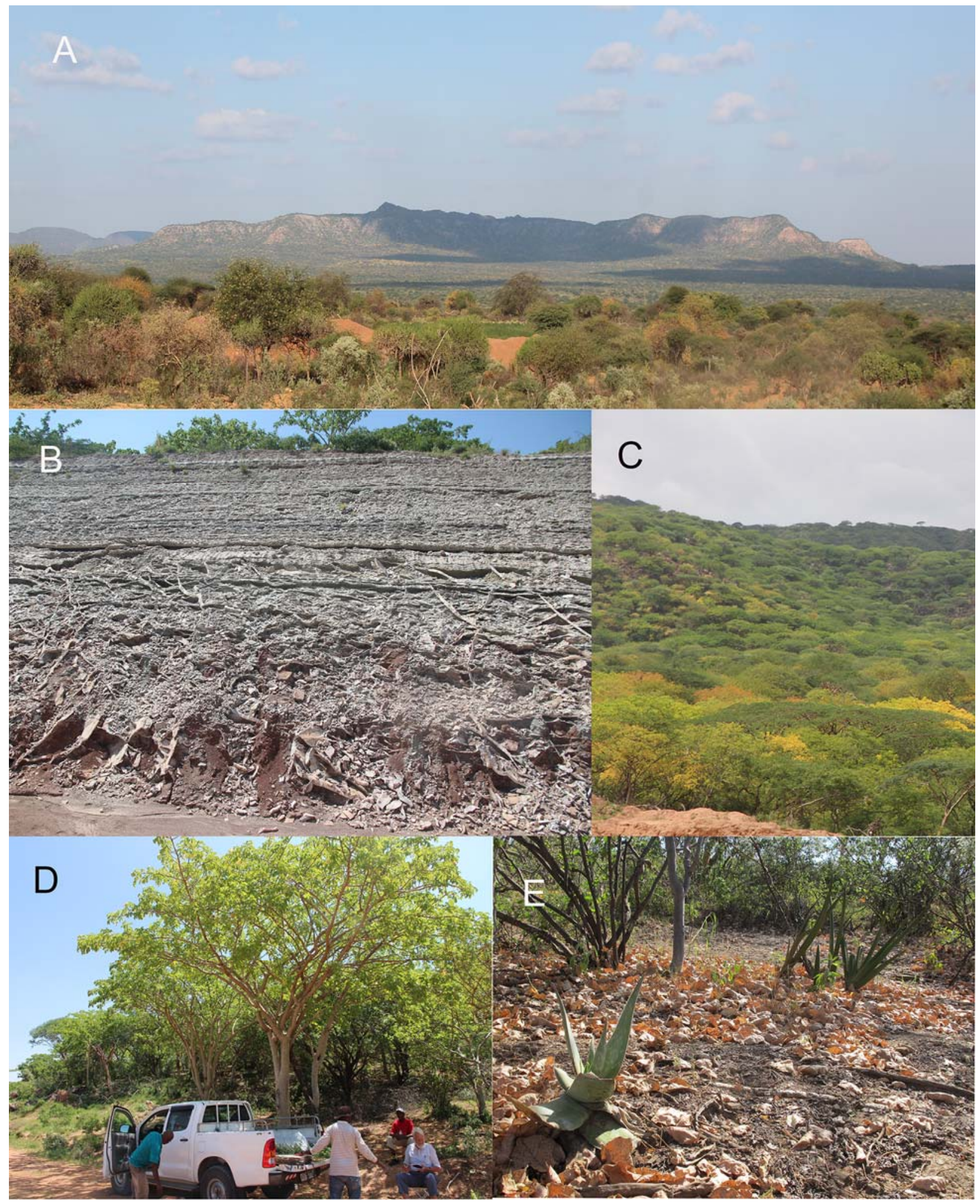

Fig. 1. A Lele Hills, seen from SW; B roadside cutting at Lele Hills, showing strata of the Gorrahei Formation; C canopy of woodland on slope of the hills, with the foliage of Commiphora guidottii turning yellow; D edge of the woodland, with $C$. guidottii as the dominant species of trees; $\mathbf{E}$ ground under the almost closed canopy of the woodland; the shrubs in the distance are almost 
certainly Commicarpus macrothamnus; the thin leaf-litter consists almost entirely of fallen leaves of C. guidottii. Photos: Ib Friis (A - B); Sebsebe Demissew (C - D); Odile Weber (E). 


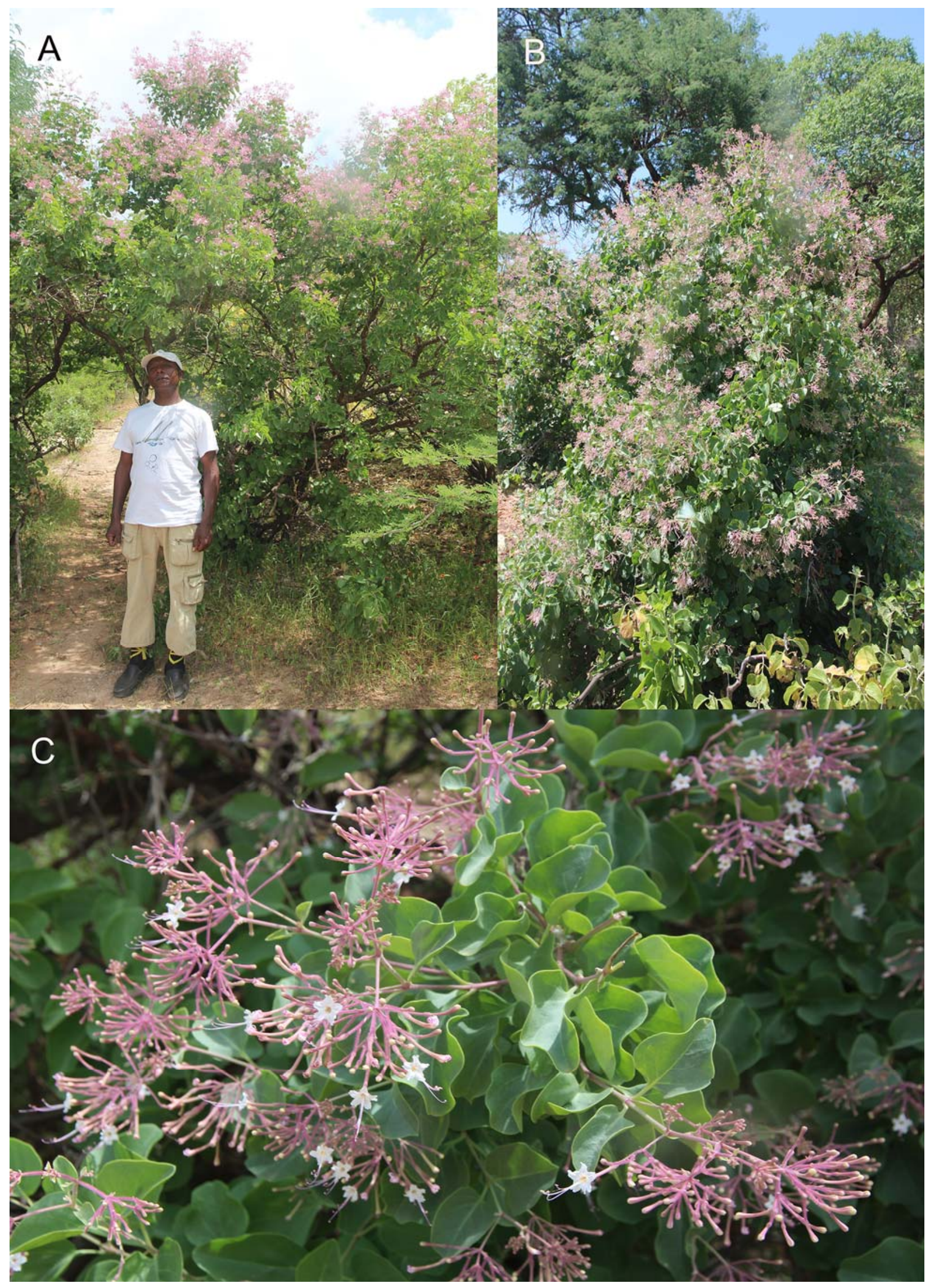


Fig. 2. Commicarpus macrothamnus. A - B habit; $\mathbf{C}$ inflorescences and undulate foliage. Photos: Ib Friis. 


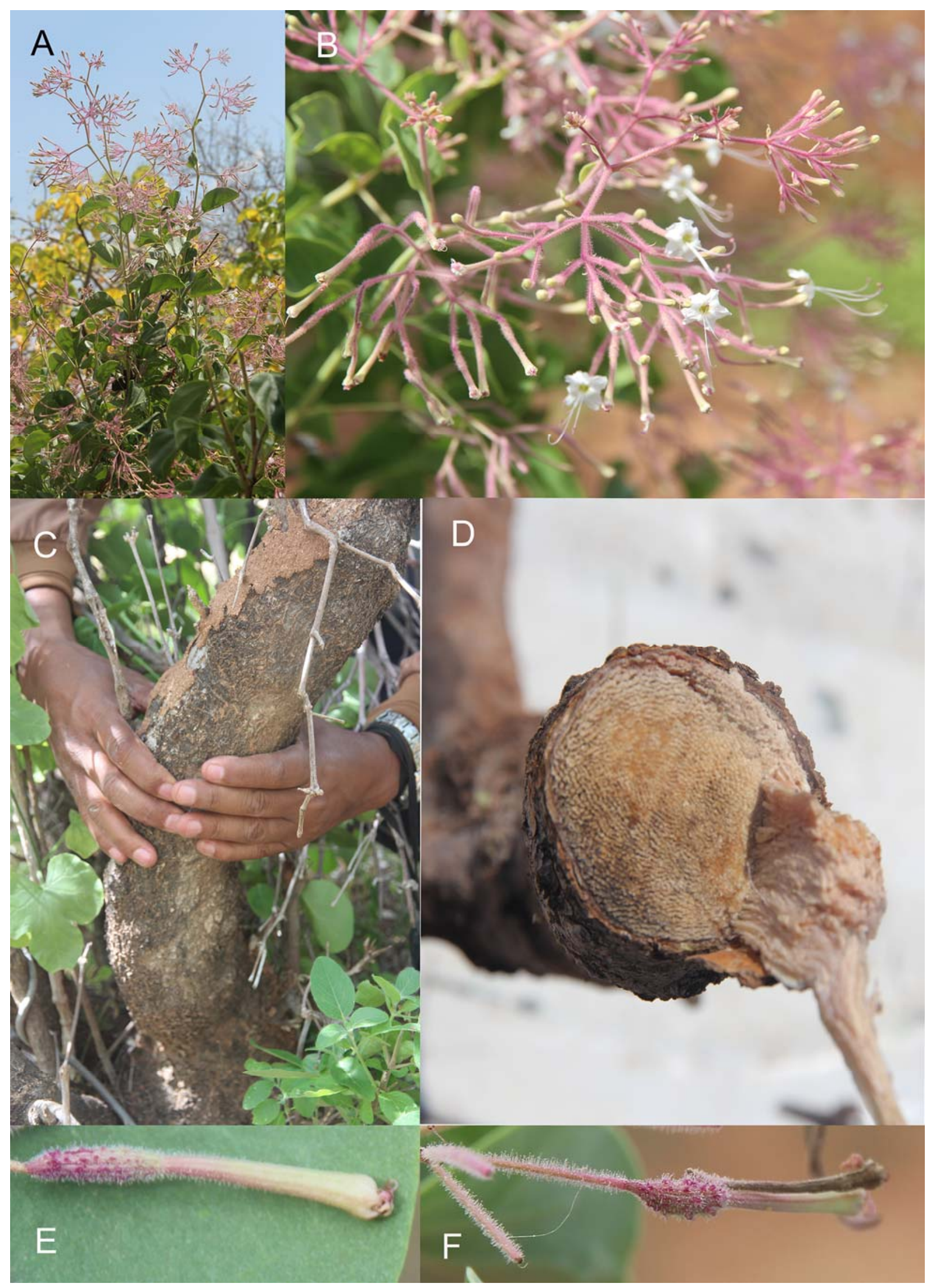


Fig. 3. Commicarpus macrothamnus. A inflorescences; B flowers; $\mathbf{C}$ intact woody stem at base; D young woody stem cut to show growth rings; E - F young anthocarps with irregularly placed sessile glands developing. Photos: Ib Friis. 


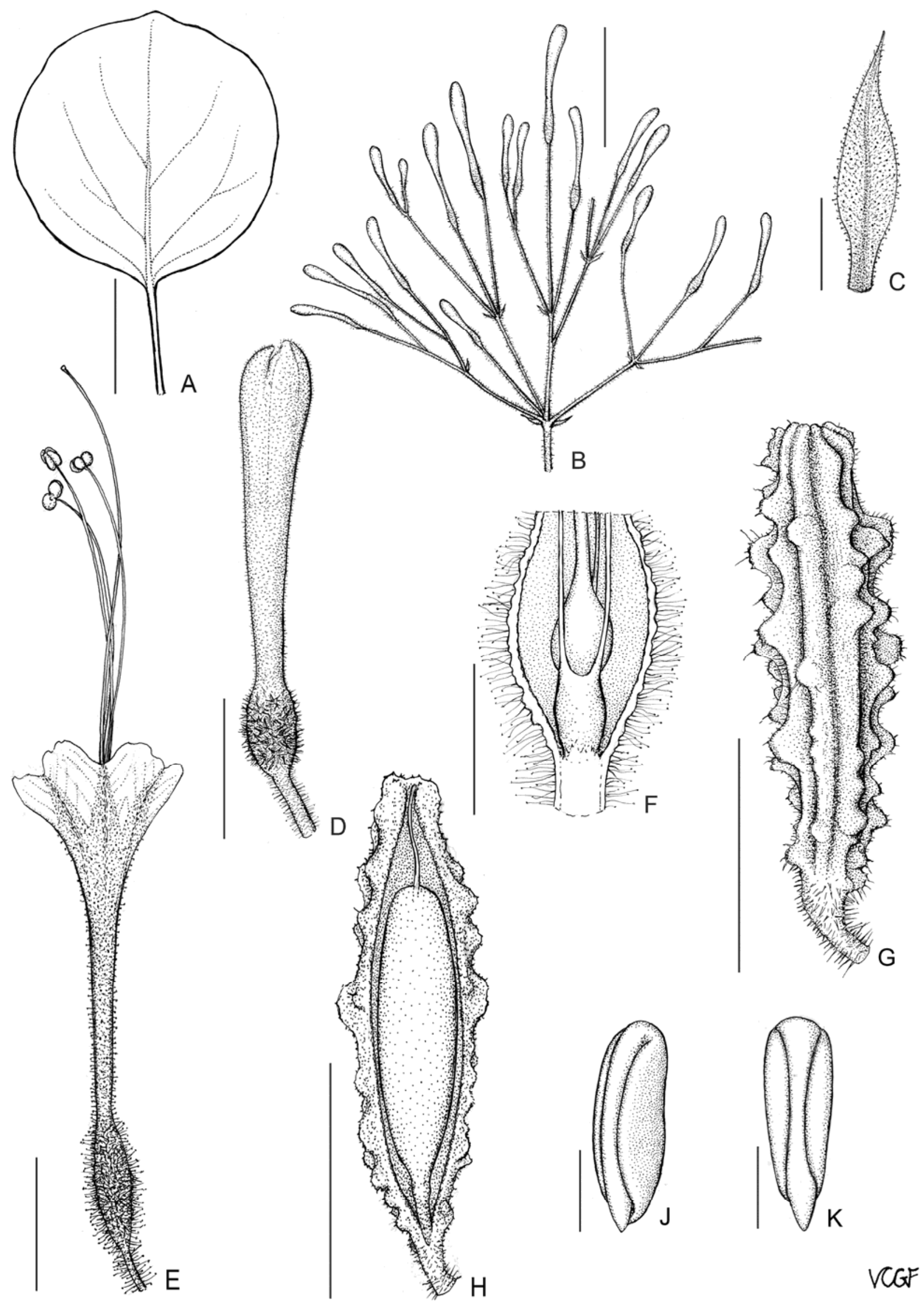


Fig. 4. Commicarpus macrothamnus. A leaf; B inflorescence; $\mathbf{C}$ bract; $\mathbf{D}$ flower bud; $\mathbf{E}$ open flower, limb not yet completely spreading; $\mathbf{F}$ young anthocarp sliced open lengthwise and widened out to show staminal tube and stipitate ovary; $\mathbf{G}$ anthocarp; $\mathbf{H}$ anthocarp opened to show fruit, no remain of staminal tube observed; $\mathbf{J}$ and $\mathbf{K}$ embryo drawn from different angles. All from Friis et al. 15492. Scale bars A, B 2 cm; D, E \& G, H 5 mm; C \& F \& J, K 2 mm. Drawn by Victoria C. G. Friis. 


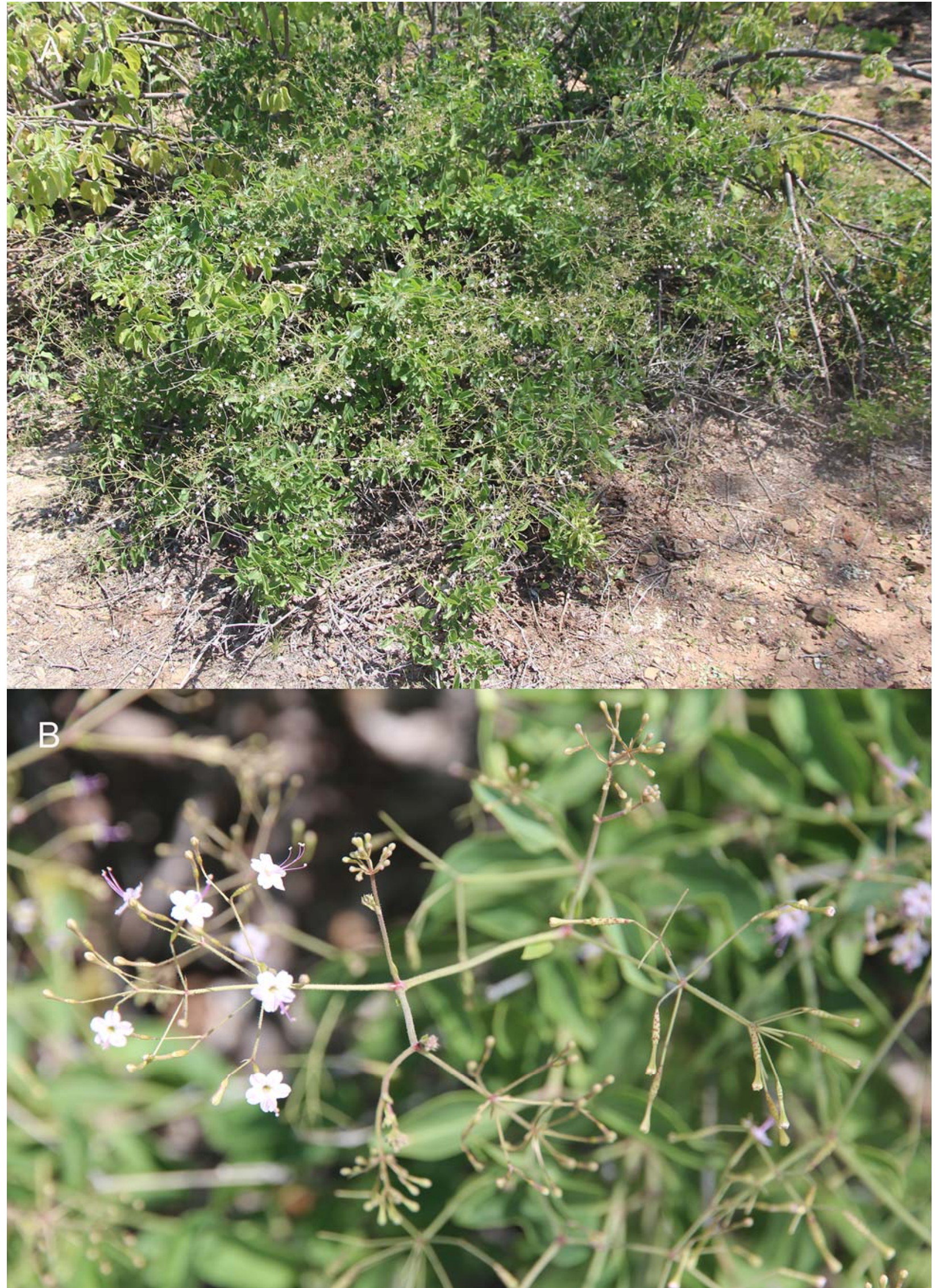


Fig. 5. Commicarpus leleensis. A habit; B inflorescence with flowers and young anthocarps. Photos: Ib Friis.
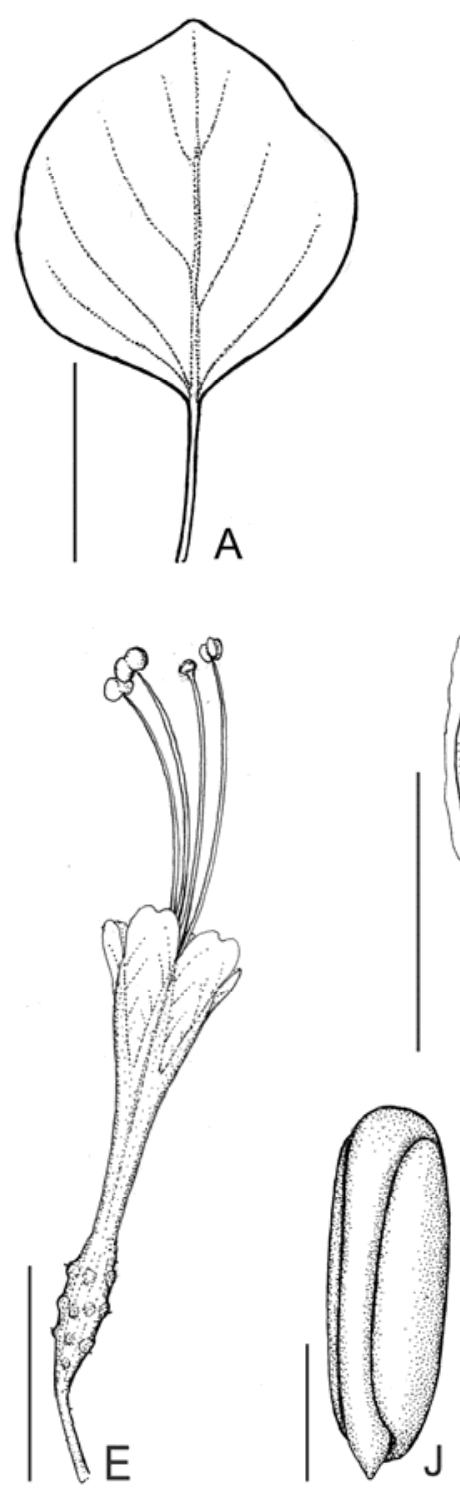
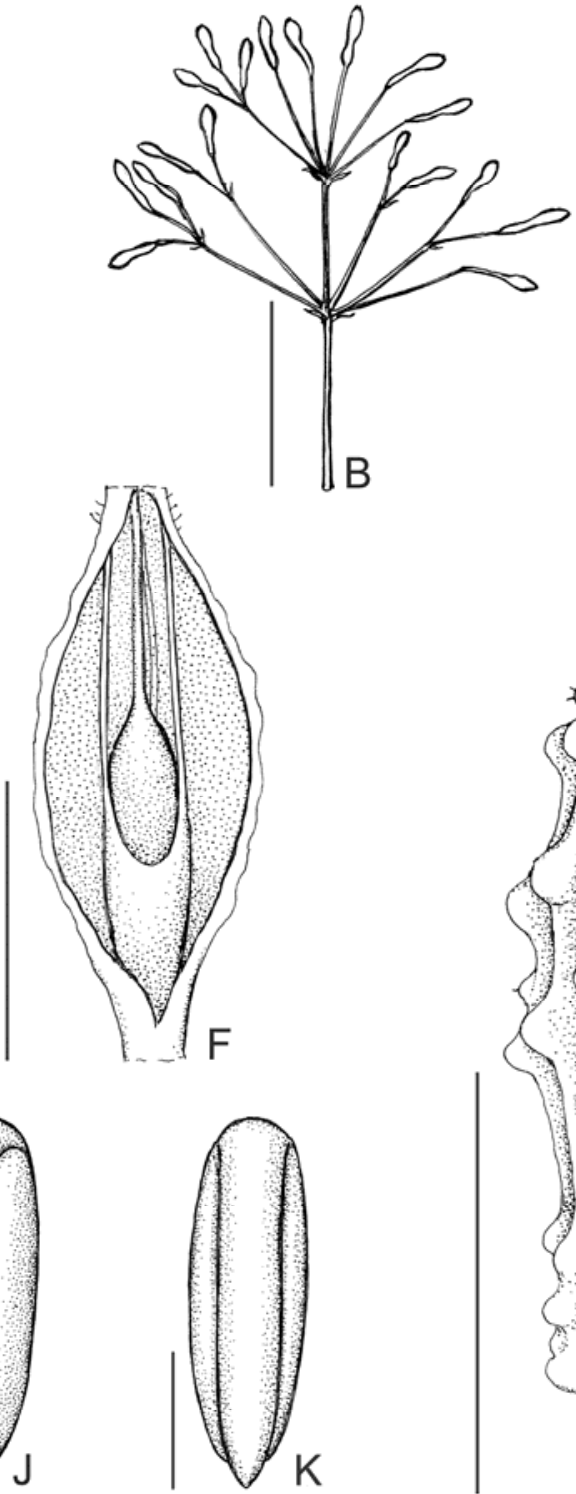
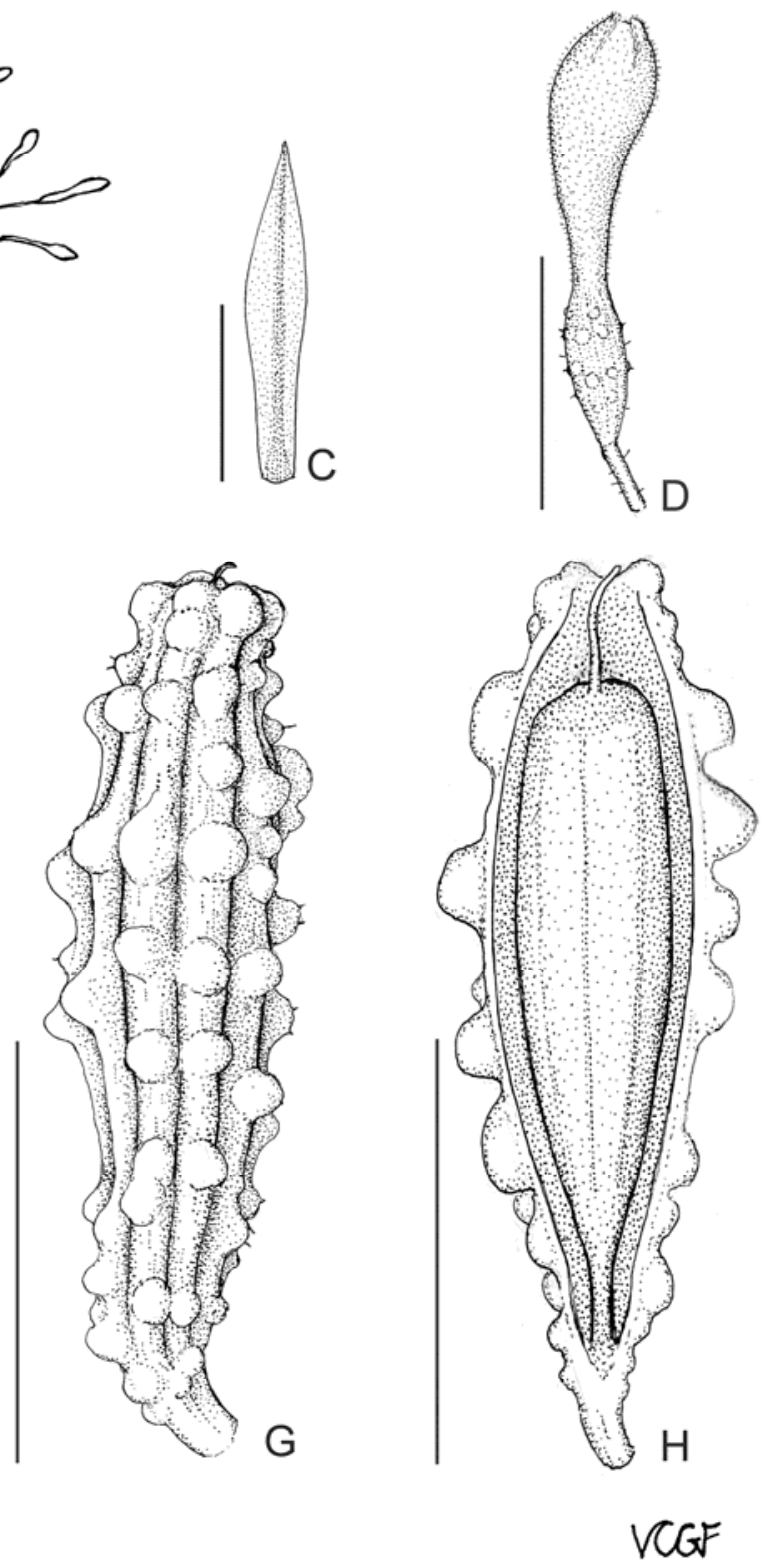

Fig. 6. Commicarpus leleensis. A leaf; B inflorescence; C bract; D flower bud; E open flower, limb not yet completely spreading; F young anthocarp sliced lengthwise and widened out to show staminal tube and stipitate ovary; $\mathbf{G}$ anthocarp; $\mathbf{H}$ anthocarp sliced lengthwise and widened out to show stipitate fruit, no remain of staminal tube observed; $\mathbf{J}$ and $\mathbf{K}$ embryo drawn from different angles. All from Friis et al. 15463. Scale bars A, B 2 cm; D, E \& G, H 5 mm; C \& F \& J, K 2 mm. Drawn by Victoria C. G. Friis. 


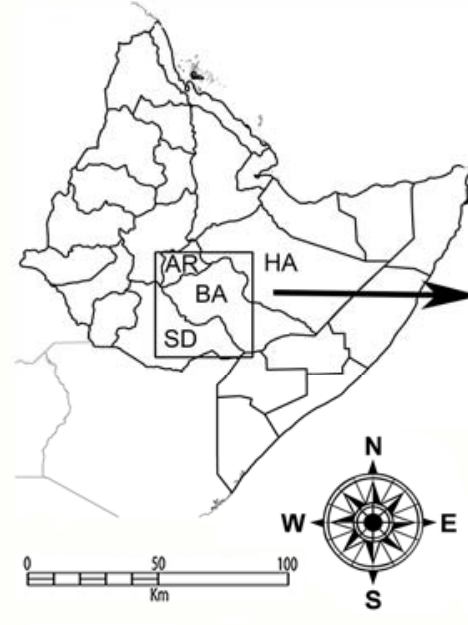

\section{Legend}
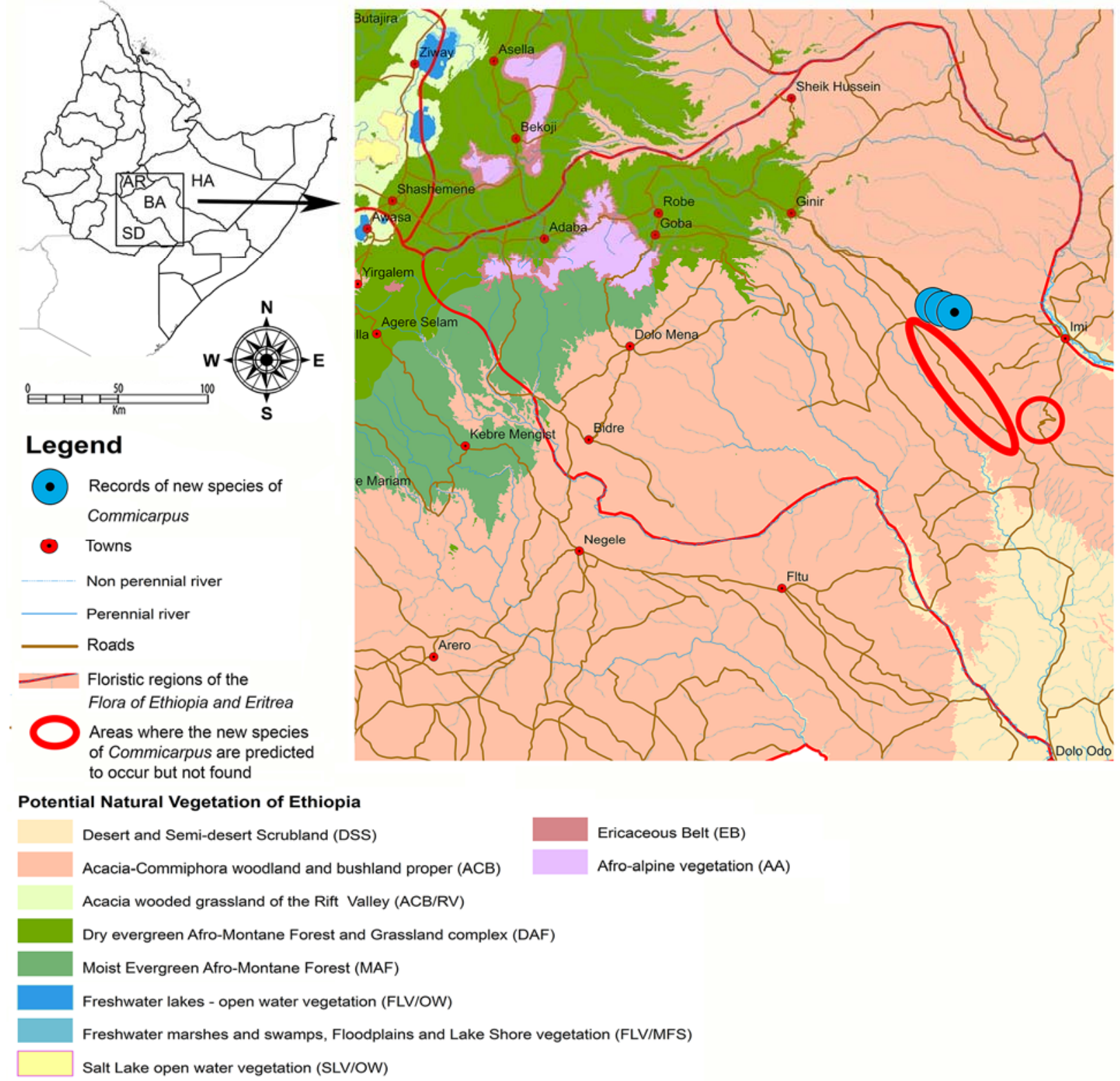

Potential Natural Vegetation of Ethiopia

ap 1. Position of localities where Commicarpus macrothamnus was observed or collected (blue bird-eye dots), and areas where the species in this paper is predicted to occur, but was not found (red lines; see also Map 2). The background is based on the map of the potential natural vegetation of Ethiopia by Friis et al. (2010); the roads between Ginir and Imi, between Ginir and Sheik Hussein and between Gobe and Bidre have been updated according to GPS track-files provided by Odile Weber. The abbreviations AR, BA, HA and SD in the overview map indicate the floristic regions used in the Flora of Ethiopia and Eritrea. Commicarpus leleensis was only recorded from the middle of the three blue bird-eye dots. 


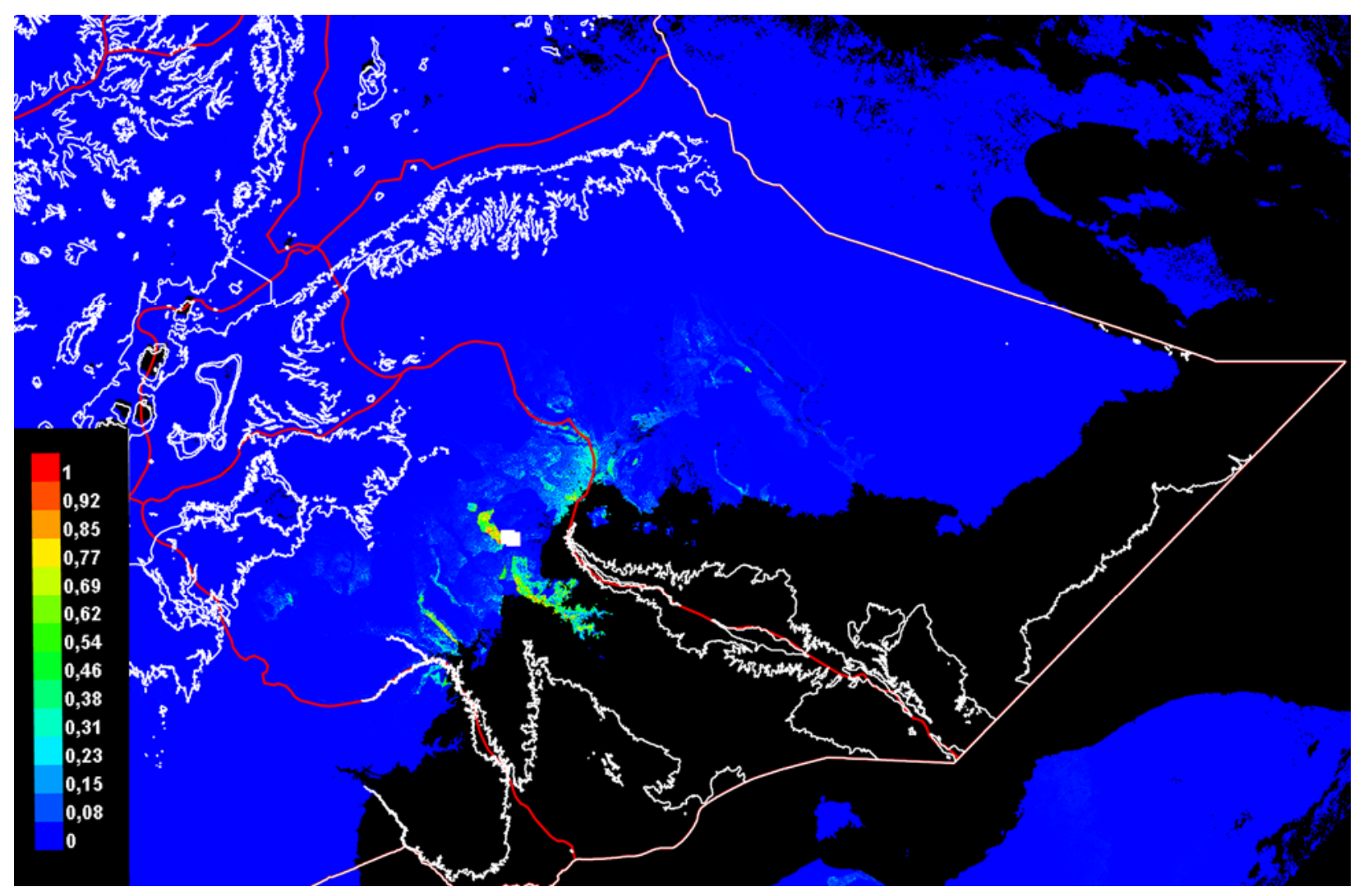

Map 2. Modelled potential distribution of Commicarpus macrothamnus, using MaxEnt 3.3 and the environmental parameters indicated in the text (climate, altitude and soil properties). The darkest red (1) indicates the highest suitability, the darkest blue the lowest (0); both the darkest blue and the black areas are unsuitable for the species. For predicted areas with high suitability, where the species was not found during field work in 2014, see Map 1. Red lines indicate borders of the floristic regions in the Flora of Ethiopia and Eritrea (brown lines in Map 1). White lines indicate borders of the potential natural vegetation of Ethiopia as proposed in Friis et al. (2010). The white squares indicate the collecting localities at the Lele Hills. 